статусу того, хто пише, і створених на папері форм / груп форм букв, слів, словосполучень, рядків; 3) викладені в роботі матеріали зорієнтовані на подальший розвиток $\mathrm{i}$ дослідження описаного психодіагностичного напрямку.

\title{
Література:
}

1. Чернов Ю. Г. Психологический анализ почерка: системный подход и компьютерная реализация в психологии, криминалистике и судебной экспертизе. Москва : Генезис, 2011. 464 с.

2. Фармагей А. И. Диагностика акцентуаций личности по почерку. Методика, описание, использование. Киев: Кий. 2010. 200 с.

3. Роршах Г. Психодиагностика: Методика и результаты диагностического эксперимента по исследованию восприятия (истолкование случайных образов). Пер. с нем. Москва : «Когито-Центр», 2003. $336 \mathrm{c}$.

4. Лурия А. Р. Высшие корковые функции человека и их нарушения при локальных поражениях мезга. 2 изд. Москва : МГУ, 1969. $504 \mathrm{c}$.

DOI https://doi.org/10.30525/978-9934-588-80-8-1.19

\section{ОСОБЛИВОСТІ СТАНОВЛЕННЯ ЦІННІСНИХ ОРІЄНТАЦІЙ СТАРШИХ ДОШКІЛЬНИКІВ В УМОВАХ СІМ'ї}

\author{
Федорчук О. I. \\ науковий співробітник \\ Лабораторія психології дошкільника \\ Інститут психологї̈ імені Г. С. Костюка \\ Начіональної академії педагогічних наук України \\ м. Київ, Україна
}

Розвиток особистості це процес виникнення принципово нових психологічних якісних новоутворень, що можливе лише в результаті активної взаємодії дитини з духовно-культурним середовищем, іншими людьми та власної цілеспрямованої активної діяльності. Для дитини таким носієм та зберігачем загальнолюдських цінностей $є$ сім'я [1, c. 14].

Формувальний вплив сім'ї на дитину є багатовекторним: чинниками виступають всі складові дитячо-батьківських взаємин і характеристики сім’ї загалом. На практиці далеко не всі чинники усвідомлюються 
батьками як такі, що мають вплив на розвиток дитини, у той час як саме не усвідомлювані чинники нерідко є більш дієвими для дитячої поведінки (О. О. Реан, Я. Л. Коломінський, О. А. Карабанова).

В рамках дослідження за темою « Специфіка становлення ціннісних орієнтацій старших дошкільників в умовах сім'ї « проведено аналіз ціннісних надбань дитини дошкільного віку в умовах родинного виховання та особливостей привласнення дитиною базових соціально значимих цінностей в сучасній сім’ї, визначено психолого-педагогічні умови становлення ціннісних орієнтацій дитини-дошкільника в родинному колі. Вивчення особливостей супроводу процесу привласнення базових соціально значимих цінностей в умовах сімейного виховання проводилось за принципами генетико-моделюючого методу (С.Д. Максименко). В ході дослідження не лише фіксувались особливості процесу внутрісімейних взаємин, а й ціленаправлено моделювались і відтворювались в реальних умовах різні форми взаємодії близького дорослого 3 дитиною. Саме такий підхід дав можливість відслідкувати процес виникнення і привласнення базових соціально значимих цінностей у дітей дошкільного віку в умовах родинного виховання. Моделюючи ситуації суб'єкт-суб'єктної взаємодії дитини 3 дорослим в процесі життєдіяльності, ми отримали можливість охарактеризувати емпіричні закономірності процесу, визначити чинники психолого-педагогічного супроводу взаємодії сім'ї і суспільного виховання дошкільників. Використаний в процесі дослідження опитувальник не лише дав можливість отримати грунтовний пласт інформації стосовно характеру і змісту внутрісімейних взаємин дитини з дорослими, іiі рольових функцій в сімейному спілкуванні, але й спонукав дорослих до глибокої рефлексії процесу сімейного виховання як провідної відповідальності батьків за соціально-психологічний розвиток дитини, осмислення нею базових правил співжиття i здатності самостійно керуватись ними у різних життєвих ситуаціях. Отримані результати експериментально підтвердили поступове формування у свідомості батьків усвідомленої необхідності ставлення до дитини як суб'єкта виховного впливу і рівноправного партнера внутрісімейних стосунків.

Як відмічав Л. Виготський, спочатку в період дошкільного дитинства вищі психічні функції (довільні) виникають як спільна діяльність дитини 3 дорослим і управління психікою дитини реалізується через посередництво дорослого, у спілкуванні дитини 3 дорослим як соціальна функція. I лише поступово такі функції стають внутрішнім надбанням дитини. Вироблення дитиною власних ціннісних орієнтацій відбувається на основі привласнення соціально 
значимих цінностей, що потребує емоційного відношення і оцінного ставлення до цінності, розвинених мисленнєвих здібностей та гармонізації цінностей 3 потребами дитини. Формування ціннісної орієнтації як якості особистості це наявність внутрішньої потреби робити, діяти, вибирати адекватно нормам, вимогам дорослих, правилам співжиття в колективі однолітків. Мова йде не про створення спеціальних умов. Сама атмосфера сім'ї має бути атмосферою любові, справедливості і відповідальності, що і сприятиме тому, щоб дитина ставала здатною зробити правильний вибір, щоб добрі ідеї стали переконаннями. Зрозуміло, що ефективність сімейної школи привласнення дитиною соціально значущих цінностей великою мірою забезпечується гармонійними виховними принципами, принаймні, батьків, повною взаємодією між ними. Адже наявність конфліктів між дорослими гостро сприймається дошкільниками і створює ситуацію вишуканого вибору одного з них в кожному окремому випадку, що суттєво руйнує весь процес особистісного зростання. Звідси і вимоги до супроводу дорослими процесу соціально-психологічного дозрівання дитини: соціальна ситуація розвитку, всі моменти життєзабезпечення дитини мають бути збагачені реальними діями, формами поведінки в суб'єктсуб'єктній взаємодії, в основі яких і закладені базові соціально значимі цінності [2, с. 52]. Саме в таких умовах дитина крок за кроком оволодіває здатністю самоуправління власною поведінкою у типових життєвих ситуаціях. Отримавши такий перший досвід в родинному оточенні дитина виходить у новий соціальний світ - колектив дитячого садка, де і створюється можливість для переносу засвоєних в сім'ї гуманних форм поведінки: взаємини з іншими дітьми, дорослими в процесі ігрової діяльності, пізнавальної і соціальної взаємодії.

Структура людських цінностей формується не на основі вроджених і підсвідомих внутрішніх тенденцій, а на грунті свідомого, осмисленого відобра-ження зовнішньої дійсності. Відбувається свідома інтелектуальна робота суб'єкта по відображенню оточуючого світу, а не розгортання внутрішніх потенцій. Засвоєний в процесі щирого i переконливого спілкування в колі сім'ї досвід співжиття та співіснування включає перші базові соціально значимі цінності.

Активна позиція дитини у відстоюванні власної суб'єктності $\epsilon$ важливим чинником іiі розвитку. Ось тому виховні зусилля дорослих мають бути спрямовані на розуміння дитини і активну допомогу їй у створенні власного світу. Їх взаємодія має вибудовуватись у форматі співробітництва, яке сприятиме розвитку обох сторін. Зрозумівши, що дитина дошкільного віку живе в особливому світі, близькі дорослі і внесуть зміни в свої ціннісні орієнтації у вихованні дитини. 
У ході дослідження ми цілеспрямовано навчали і переконували батьків у глибоких виховних можливостях суб'єкт-суб'єктної взаємодії 3 дітьми, яка $є$ адекватною їх природнім силам і спрямована на формування особистості в єдності емоційних, особистісних і поведінкових надбань. Особлива роль дорослих полягає у здатності створювати сприятливу атмосферу для самовиявлення дитини, у вмінні радіти за неї, збуджувати іiї уяву для пошуку власних способів дії, ініціювати висловлювання своєї думки, навчати чути і осмислювати іншу думку, піддавати іiі сумніву і водночас переконливо доводити свою відмінну оцінку. Завданням для дорослого полягає у створенні ситуації для широкого орієнтування дитини в змістовому просторі яка би сприяла розширенню меж для свободи дитячої фантазії, активізації ініціативи, збільшенню варіативності пошуків, налаштуванню діалогу 3 партнерами. Включення в активний процес взаємодії дає дитині можливість відчути себе творцем важливої справи, є поштовхом для сплеску емоцій «Я хочу, можу, буду!». Це $є$ гуманно-особистісним підходом у вихованні дітей: віра в їх можливості, розкриття їх самобутності, повага до індивідуальності і внутрішнього світу дитини.

Основними в структурі ціннісних орієнтацій є знання і почуття. А основною умовою сприйняття дитиною суспільно значимих цінностей як особистісного смислу є єдність, адекватне співвідношення знань i почуттів в самому процесі сприйняття особистістю дійсності. Ось чому саме в сімейному товаристві, а, можливо, і лише в ньому, дитина вже в дошкільному віці отримує безцінний досвід для становлення іiі як особистості, досвід людини як свідомого учасника соціального буття. Поступово в старших дошкільників зароджується здатність емоційно переживати прояви добра, емпатії, справедливості в непов'язаних 3 дитиною життєвих моментах: конкретні смисли стають значущими для даної дитини, формуючи основу індивідуальної культури цінностей окремої особистості.

Одним 3 основних завдань фахового психолого-педагогічного супроводу батьківсько-дитячих стосунків має бути детальне роз'яснення сучасним молодим сім'ям розуміння того, що моделі людської поведінки дитина пізнає в сім'ї: через відношення до себе; стосунки між дорослими в родині; реакції дорослих на позитивні і негативні дитячі поведінкові прояви. Вцілому відслідковування процесу привласнення дитиною базових соціальних цінностей допомагає з'ясувати процес усвідомлення нею реального сенсу життя, відчуття власних потреб і мотивів поведінки. Лише на такому тлі і можна опосередковано спрямовувати дитину до вибору вчинку на користь чуйності до переживань іншого, спонукаючи рефлексію гідного самоставлення. Власне так і відбувається осмислення 
дитиною свого місця в світі («Я»-соціальне, цілісне як основа самодостатньої особистості, коли виникає гармонія серця, розуму і волі (Г. Костюк).

\title{
Література:
}

1. Максименко С.Д. Проблеми прогнозування психічного розвитку дитини. Проблеми девіантної поведінки: історія, теорія, практика : Матеріали Всеукраїнської науково-практичної конференції (2527 листопада 2002). Київ: Міленіум, 2002. С. 3-29.

2. Прийняття дитиною цінностей: посібник / Т.О. Піроженко, I.I. Карабаєва, С.О. Ладивір, Л.І. Соловйова та ін., за ред. Т.О. Піроженко. Київ: Видавничий Дім «Слово», 2018. 240 с.

DOI https://doi.org/10.30525/978-9934-588-80-8-1.20

\section{ПАТОГЕНЕЗ ДЕПРЕСИВНИХ СТАНІВ ТА ЇХ ВПЛИВ НА ПСИХОСОМАТИЧНЕ ЗДОРОВ'Я}

\author{
Чистовська Ю. Ю. \\ кандидат психологічних наук, доиент кафедри психології \\ Черкаський національний університет імені Богдана Хмельницького \\ м. Черкаси, Україна
}

Загальновизнано, що виникнення депресій мультикаузально, тобто широкий спектр біологічних, середовищних та психологічних факторів можуть зробити свій внесок в генезис депресивних розладів. За останні роки з'явилось багато різних концепцій, що намагаються вияснити роль цих факторів впливу. I з самого початку не відчувалося нестачі в роботах, що намагалися підвести спільну теоретичну базу під окремі напрямки досліджень, але останнім часом кількість таких робіт значно збільшилась i намітилась тенденція до розвитку інтегративних «біопсихосоціальних» моделей депресії. Хоча такі моделі в деталях значно відрізняються одна від одної, проте у всіх них, як правило, значне місце займає гіпотеза взаємодії стресових середовищних факторів і індивідуальних рис схильності - гіпотеза діатезу - стресу.

При виявленні депресії та з'ясуванні іï впливу на психосоматичні розлади існують певні об'єктивні фактори, що ускладнюють виявлення i iii клінічну диференціацію. Достатньо лише виділити коморбідні зв'язки афективних розладів як 3 психічною, так i 3 соматичною 